\title{
22. ORE MINERALOGY OF SOUTH ATLANTIC BASALTS (DEEP SEA DRILLING PROJECT LEG 73) ${ }^{1}$
}

\author{
Nikolai Petersen, Institut für Allgemeine und Angewandte Geophysik, Universität München, \\ Theresienstr. 41, D-8000 Munich, Federal Republic of Germany
}

\section{INTRODUCTION}

The samples investigated in this study come from DSDP Leg 73 Drill Holes 519A, 522B, and 524, all of which are in the South Atlantic. A general petrographic description of the basalts is given by Carman et al. (this vol.). Location, age (based on marine magnetic anomaly identification), and general magnetic properties of the basalts are given in Table 1 .

\section{METHODS}

\section{Microscopic Observations}

For ore microscopic observation, polished sections were studied under reflected light using a Leitz Ortholux Pol microscope. Magnetic colloid was used to aid in the identification of the magnetic minerals.

\section{Electron Microprobe Analyses}

The microprobe analyses of the ore minerals contained in the basalts were performed with a Geoscan (Cambridge Instruments) electron microprobe equipped with two spectrometers. The ore grains selected for the microprobe analyses had to be homogeneous and larger than $10 \mu \mathrm{m}$ in diameter. The samples were prepared as polished sections and coated with a thin carbon layer. An acceleration voltage of $20 \mathrm{kV}$ and a specimen current of $40 \mu \mathrm{A}$ were used with a 20 -s counting period.

On the average, three-point analyses per mineral grain and 10 grains of each mineral within a sample (as far as possible) were analyzed. All $\mathrm{Fe}-\mathrm{Ti}$ oxides were analyzed for $\mathrm{Fe}, \mathrm{Ti}, \mathrm{Al}, \mathrm{Mg}, \mathrm{Mn}$, and $\mathrm{Si}$. The last-mentioned element was measured to estimate the effect of the surrounding silicate matrix and to reject analyses giving excessive $\mathrm{Si}$ contents, on the assumption that $\mathrm{Fe}-\mathrm{Ti}$ oxides do not contain $\mathrm{Si}$. The iron-sulfide minerals were analyzed for $\mathrm{Fe}, \mathrm{Co}, \mathrm{Ni}, \mathrm{Cu}, \mathrm{S}$, and $\mathrm{Sb}$. The results are given as weight percentages of the elements instead of the usual oxide percentages, since oxygen cannot be measured with the microprobe used in this study.

\section{Thermomagnetic Curves}

The Curie temperature $\left(T_{c}\right)$ and specific saturation magnetization $\left(I_{s}\right)$ of the bulk rock material were determined by measuring the temperature dependence of the strong field-induced magnetization with a Forrer

\footnotetext{
${ }^{1}$ Hsü, K. J., LaBrecque, J. L., et al., Init. Repts. DSDP, 73: Washington (U.S. Govt. Printing Office).
}

Table 1. Location, age, mean natural remanent magnetization (NRM), and mean susceptibility of basalts from DSDP Leg 73 (South Atlantic).

\begin{tabular}{ccccc}
\hline Hole & Location & $\begin{array}{c}\text { Basalt } \\
\text { age } \\
(\mathrm{m} . \mathrm{y} .)\end{array}$ & $\begin{array}{c}\text { Mean NRM } \\
\left(10^{-4} \mathrm{G}\right)\end{array}$ & $\begin{array}{c}\text { Mean susceptibility } \\
\left(10^{-4} \mathrm{G} / \mathrm{O}\right)\end{array}$ \\
\hline $519 \mathrm{~A}$ & $26^{\circ} 8.20^{\prime} \mathrm{S}, 1^{\circ} 39.97^{\prime} \mathrm{W}$ & $10-12$ & $\begin{array}{c}13.1 \pm 17^{7} \\
(\mathrm{n}=23)^{\mathrm{b}}\end{array}$ & $\begin{array}{c}5.7 \pm 2.0 \\
(\mathrm{n}=23)\end{array}$ \\
$522 \mathrm{~B}$ & $26^{\circ} 6.84^{\prime} \mathrm{S}, 5^{\circ} 7.78^{\prime} \mathrm{W}$ & 40 & $\begin{array}{c}37.6 \pm 2.0 \\
(\mathrm{n}=15)\end{array}$ & $\begin{array}{l}6.8 \pm 2.1 \\
(\mathrm{n}=15)\end{array}$ \\
524 & $29^{\circ} 29.07^{\prime} \mathrm{S}, 3^{\circ} 30.74^{\prime} \mathrm{W}$ & $70-75$ & $\begin{array}{c}42.8 \pm 2.4 \\
(\mathrm{n}=43)\end{array}$ & $\begin{array}{c}24.1 \pm 2.9 \\
(\mathrm{n}=21)\end{array}$ \\
\end{tabular}

a Previous NRM and susceptibility measurements of South Atlantic basalts (Lowrie, 1977) give considerably lower values. The values presented here fit better into the general picture of ocean floor basalts.

$\mathrm{b} \mathrm{n}=$ number of samples analyzed.

automatically recording translation balance; the applied magnetic field was 1800 Oe. The samples were heated in air. From the thermomagnetic curves the Curie temperatures were determined by using the graphical method of Grommé et al. (1969).

\section{Determination of the Titanomagnetite Low Temperature Oxidation Parameter}

The titanomagnetite low temperature oxidation parameter (z) was determined from the Curie temperatures by using the relationship given by Petersen et al. (1979). $z$ has been defined by O'Reilly and Banerjee (1966) as the fraction of the initial $\mathrm{Fe}^{2+}$ in the titanomagnetite converted to $\mathrm{Fe}^{3+}$. Unoxidized titanomagnetite is characterized by $\mathrm{z}=0$, and completely oxidized titanomagnetite by $z=1$.

\section{RESULTS}

\section{Microscopic Observations}

\section{Hole 519A}

The entire sequence of basalt recovered in this hole consists of aphyric olivine basalt, all of which is from massive flow units, with the possible exception of a thin unit at the base of Flow Unit 2 (see Carman et al., this vol.). Titanomagnetite, ilmenite, various iron sulfides, and chromium spinel were identified as ore minerals.

\section{Titanomagnetite}

Most abundant of the opaque minerals is titanomagnetite. It makes up about $80 \mathrm{vol} . \%$ of the opaque minerals. The titanomagnetite grains are responsible for the magnetization of the basalts; the contribution of the other minerals can be neglected. The grain size of the 
titanomagnetites varies from almost invisible even under highest magnification (Samples 519A-7-1, 72-74 cm, 519A-7-1, 55-57 cm, and 519A-8-2, 47-49 cm) to about $100 \mu \mathrm{m}$ in diameter (Samples 519A-7-2, 50-52 cm, 519A-8-1, 12-14 cm, and 519A-9-3, 59-61 cm). Their shape is skeletal to subhedral (Fig. 1). The titanomagnetites are frequently concentrated in the glassy patches that are interstitial between the feldspar laths. This is particularly evident in the coarse-grained samples with ophitic texture (Samples 519A-7-2, 50-52 cm, 519A-8-1, $12-14 \mathrm{~cm}$, and 519A-9-3, 59-61 cm). The titanomagnetites look fresh under the microscope in all investigated samples, even in samples where brownish colors sometimes signal a certain degree of whole rock alteration. In Sample 519A-8-1 (13-15 cm), titanomagnetite grains occasionally show exsolved ilmenite lamellae, an indication of deuteric high temperature oxidation, a rare phenomenon in ocean floor basalts. According to Johnson and Hall (1978) and Petersen et al. (1979), in ocean floor basalts it is restricted to the center parts of massive flows.

\section{Ilmenite}

Discrete primary ilmenite grains have been identified in all samples from this site. Their volume content is much lower than that of the titanomagnetites. Under the microscope the ilmenite grains appear mostly as laths; in Sample 519A-8-1 (13-15 cm) they are up to $200 \mu \mathrm{m}$ in length.

\section{Iron Sulfides}

Iron sulfides are abundant in all samples. They form small spherules, thus indicating the immiscibility of sulfide and silicate melt (Fig. 2). The dominant sulfide mineral is pyrrhotite.

\section{Chromium Spinel}

Chromium spinel has been observed in Sample 519A8-3 (82-84 cm), where it forms the core of isolated euhedral titanomagnetite grains (Fig. 3).

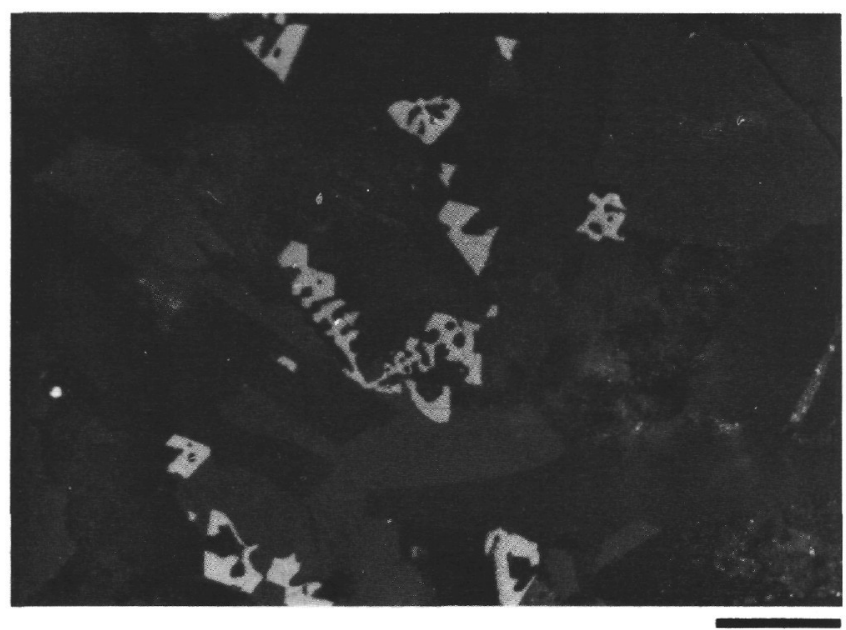

$20 \mu \mathrm{m}$

Figure 1. Skeletal titanomagnetite (gray) in ocean floor basalt. Sample 519A-7-2 (50-52 cm).

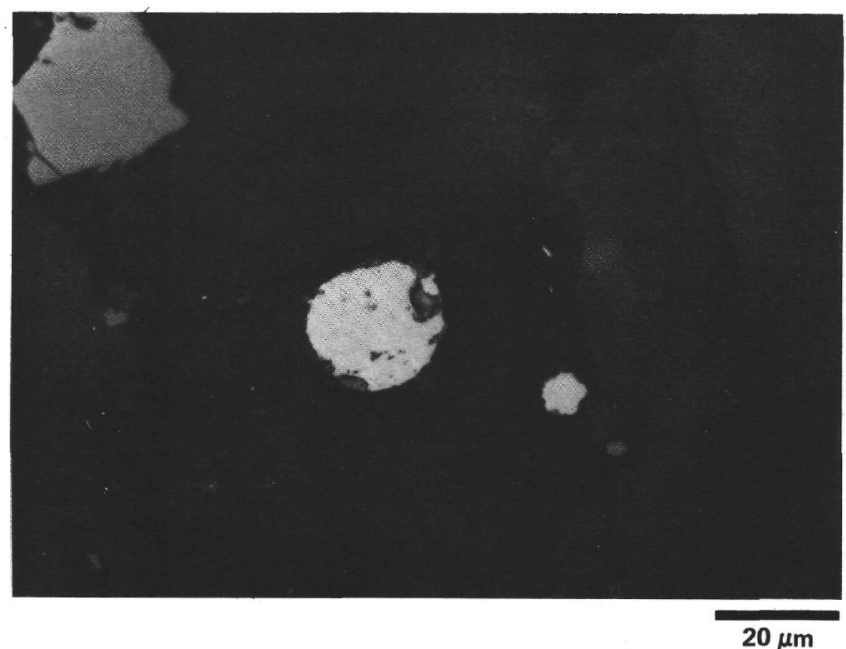

Figure 2. Spherical sulfide globules (white) consisting of pyrrhotite. In the upper left corner of the photograph subhedral titanomagnetite appears (gray). Sample 519A-7-2 (50-52 cm).

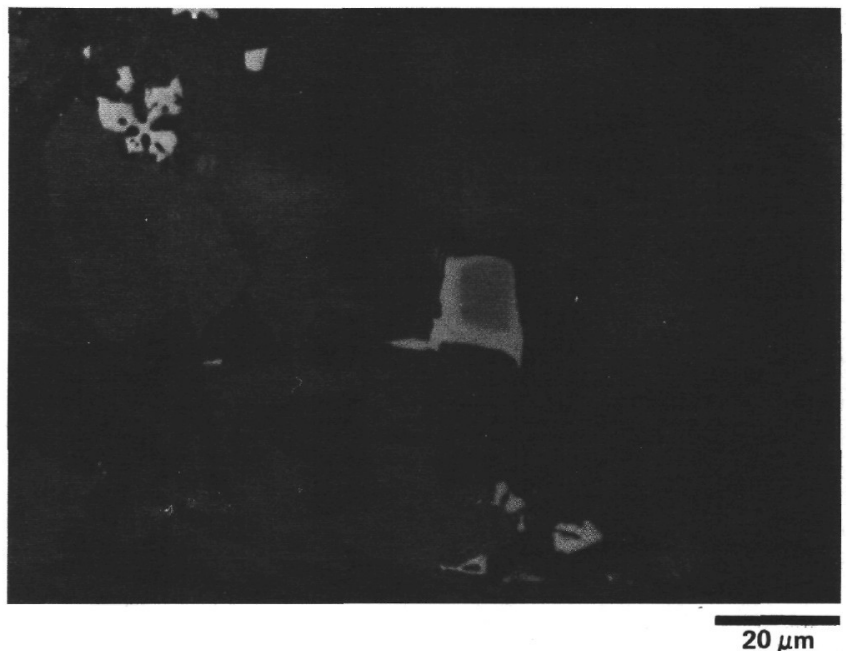

Figure 3. Euhedral titanomagnetite (gray) with core of chromium spinel (dark gray). In the upper left corner of the photograph skeletal titanomagnetite appears. Sample 519A-8-2 (129-131 cm).

\section{Hole 522B}

The sequence recovered from Hole 522B consists of several cooling units of aphyric olivine basalt; the units are interpreted as both pillows and flows (Carman et al., this vol.).

The opaque mineralogy of the basalts of this site is similar to the mineralogy of Hole 519A. However, no signs of titanomagnetite high temperature deuteric oxidation (titanomagnetite ilmenite exsolution) have been observed. Chromium spinel has not been observed either. The grain sizes of the Fe-Ti oxides are generally smaller than in Hole 519A.

\section{Hole 524}

At Site 524, basaltic rock was encountered at three different intervals and was interlayered with sedimentary rocks. The first interval (Unit 1), which occurred in 
Core 28 , is about $0.50 \mathrm{~m}$ thick and is interpreted as pillows (Carman et al., this vol.). The second and third units are about $16 \mathrm{~m}$ thick (Unit 2, Cores 29-32) and $9 \mathrm{~m}$ thick (Unit 3, Cores 32-34). Units 2 and 3 may represent sills.

Units 1 and 2 are different from Unit 3. In Units 1 and 2, primary ilmenite is by far the most common opaque mineral phase. Titanomagnetite is present in form of subhedral to euhedral crystals.

In the upper portion of Unit 2 (Core 30), the titanomagnetite crystals show well developed exsolution lamellae of ilmenite, evidence of high temperature deuteric oxidation. The extent of deuteric oxidation observed in this portion is atypical for ocean floor basalts and shows rather a resemblance to titanomagnetite oxidation in subaerial basalts. Pyrrhotite is very rare in this portion of Unit 2. In Sample 524-30-2 (59-61 cm), however, there is a macroscopically visible vein of secondary pyrite (Fig. 4).

The lower portion of Unit 2 (Cores $\mathbf{3 1}$ and 32) is different from the upper portion of this unit in that it does not show any signs of titanomagnetite deuteric oxidation. Here, volume change cracks in the titanomagnetites (described as a common feature in ocean floor basalts by Johnson and Hall, 1978, and Petersen et al., 1979) give evidence of extensive low temperature oxidation (Fig. 5). This is the typical form of titanomagnetite seafloor alteration. Pyrrhotite is more common in this portion of Unit 2.

In Unit 3 (Cores 32-34), skeletal to subhedral titanomagnetite is the dominant ore mineral; ilmenite is observed only occasionally. Pyrrhotite is present as small spherules. Volume change cracks in the titanomagnetite grains are well developed, again giving evidence of widespread low temperature oxidation (Fig. 6). In Sample 524-34-2 $(13-15 \mathrm{~cm})$, both volume change cracks and ilmenite exsolution lamellae are present in the titanomagnetite grains. In this sample there are occasional thin veins of secondary pyrite.

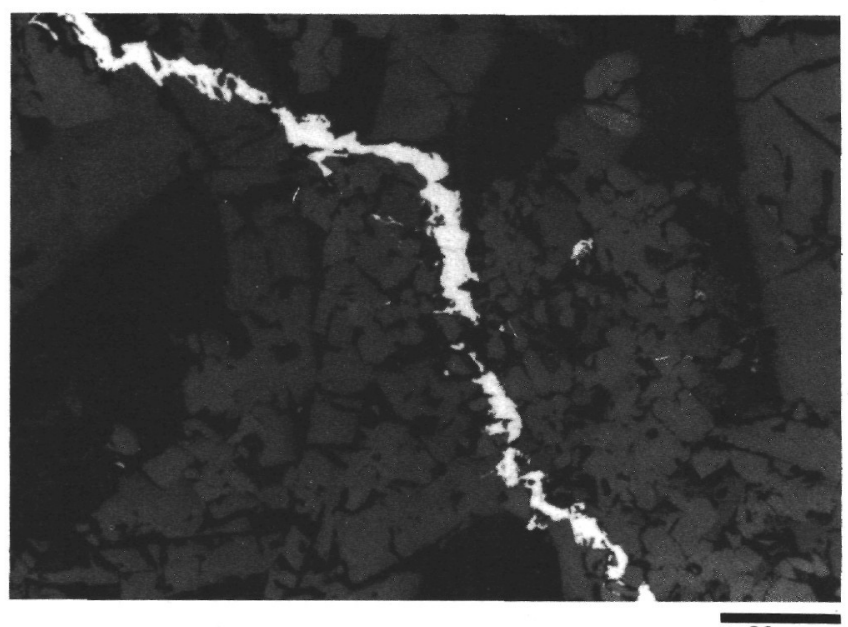

$20 \mu \mathrm{m}$

Figure 4. Vein of secondary pyrite (white) in ocean floor basalt. Sample 524-30-2 (59-61 cm).

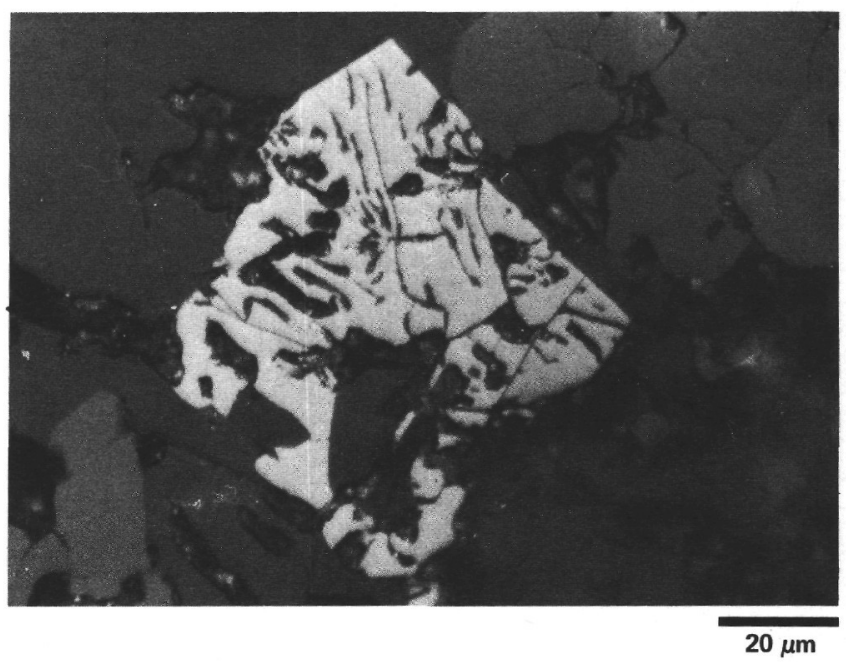

Figure 5. Extensive development of volume change cracks in skeletal to anhedral titanomagnetite. Sample 524-31-2 (61-63 cm).

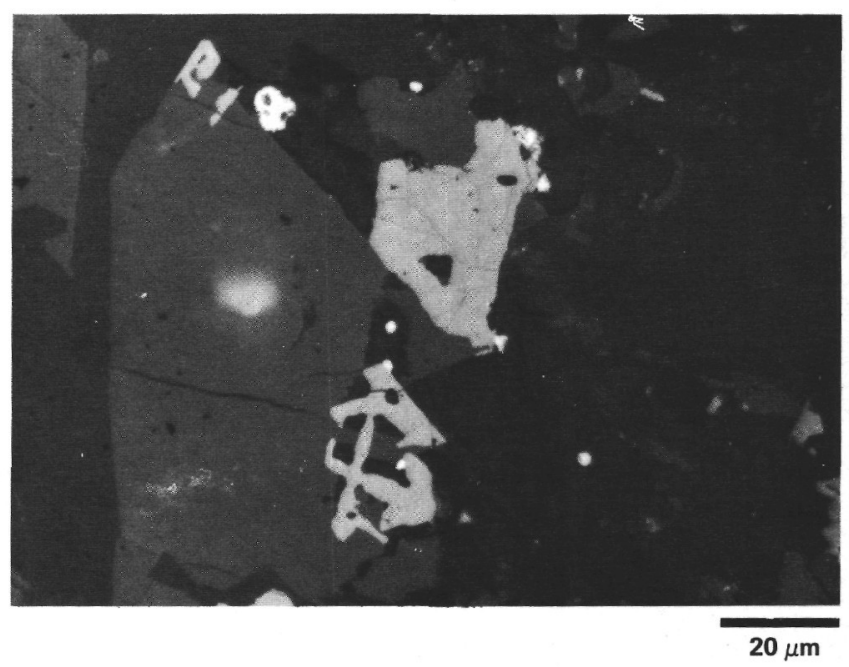

Figure 6. Limited development of volume change cracks in anhedral and skeletal titanomagnetite grains. Sample 524-33-2 (104-106 cm).

\section{Chemical Composition of the Ore Minerals}

The results of the microprobe analyses, together with bulk rock Curie temperatures $\left(T_{c}\right)$ and values of specific saturation magnetization $\left(I_{s}\right)$, are presented in Table 2 . For samples with no signs of titanomagnetite high temperature deuteric oxidation, the titanomagnetite low temperature oxidation parameter $\mathrm{z}$ has been determined from the Curie temperatures, and it is also included in Table 2.

The titanomagnetites analyzed in this study all show a certain degree of nonstoichiometry due to the effect of ocean floor low temperature oxidation; that is, the titanomagnetites are cation-deficient spinels. The degree of cation deficiency is expressed in Table 2 by the oxidation parameter $\mathrm{z}(0 \leq \mathrm{z} \leq 1)$. The composition of the original unoxidized titanomagnetites cannot therefore be re- 


\section{N. PETERSEN}

Table 2. Microprobe analysis results (wt.\%) of the ore minerals contained in the DSDP Leg 73 basalts, Curie temperature $\left(\mathrm{T}_{\mathrm{c}}\right)$ and specific saturation magnetization $\left(\mathrm{I}_{\mathrm{S}}\right)$ of the bulk rock material, and titanomagnetite low temperature oxidation parameter $\mathrm{z}(0 \leq \mathrm{z} \leq 1)$.

\begin{tabular}{|c|c|c|c|c|c|c|c|c|c|c|c|c|c|c|c|}
\hline $\begin{array}{c}\text { Sample } \\
\text { (interval in cm) }\end{array}$ & $\mathrm{Fe}$ & $\mathrm{Ti}$ & Mg & $\mathrm{Al}$ & Mn & $\mathrm{Si}$ & $\mathbf{s}$ & & Co & $\mathrm{Ni}$ & $\mathrm{Sb}$ & Mineral & $\begin{array}{c}\mathrm{T}_{\mathrm{c}} \\
\left({ }^{\circ} \mathrm{C}\right)\end{array}$ & $\left(10^{-2} \mathrm{G} \mathrm{cm}^{\mathrm{I}_{\mathrm{S}}} \mathrm{g}^{3}-1\right)$ & $z$ \\
\hline $519 \mathrm{~A}-7-1,107-109$ & $54.46 \pm 2.34$ & $12.32 \pm 1.41$ & $0.42 \pm 0.12$ & $0.79 \pm 0.10$ & $0.44 \pm 0.07$ & $0.19 \pm 0.07$ & - & & - & - & - & Titanomagnetite & 285 & 45 & 0.69 \\
\hline \multirow[t]{3}{*}{$519 A-8-1,13-15$} & $54.81 \pm 0.30$ & $13.80 \pm 0.20$ & $0.50 \pm 0.10$ & $0.75 \pm 0.08$ & $0.39 \pm 0.06$ & $0.07 \pm 0.01$ & - & & - & - & - & Titanomagnetite & 180 & 60 & (a) \\
\hline & $59.54 \pm 0$. & - & - & - & - & - & $38.67 \pm 0.88$ & $0.25=$ & \pm 0.01 & $0.43 \pm 0.35$ & - & Pyrrhotite & & & \\
\hline & $46.83 \pm 0.08$ & $112 \overline{+}$ & $0.51 \pm 0.17$ & $0-$ & $041 \pm 013$ & - & $52.53 \pm 0.85$ & 0.07 & \pm 0.04 & - & - & Pyrite & & & \\
\hline $519 \mathrm{~A}-8-2,129-131$ & $\begin{array}{l}55.19 \pm 3.23 \\
37.31 \pm 0.51\end{array}$ & $\begin{array}{l}11.12 \pm 1.53 \\
28.99 \pm 0.28\end{array}$ & $0.74 \pm 0.22$ & $\begin{array}{l}0.94 \pm 0.18 \\
0.06 \pm 0.01\end{array}$ & $0.41 \pm 0.13$ & $0.11 \pm 0.05$ & $=$ & & $\bar{z}$ & $=$ & $\bar{z}$ - & $\begin{array}{l}\text { Titanomagnetite } \\
\text { Vlmenite }\end{array}$ & 345 & 48 & 0.80 \\
\hline \multirow[t]{2}{*}{ 519A-9-4, 96-98 } & $\begin{array}{l}53.56 \pm 0.31 \\
53.66\end{array}$ & $13.75 \pm 1.02$ & $0.88 \pm 0.22$ & $0.83 \pm 0.20$ & $0.35 \pm 0.10$ & $0.11 \pm 0.08$ & $\bar{z}$ & & $\overline{-}$ & $\bar{z}$ & $\overline{-}$ & Titanomagnetite & 270 & 25 & 0.66 \\
\hline & $\begin{array}{l}36.71 \\
59.50 \pm 0.45\end{array}$ & 29.50 & 0.94 & 0.05 & 0.29 & 0.03 & - & & - & - & - & Ilmenite & & & \\
\hline $522 \mathrm{~B}-4-1,3-5$ & $\begin{array}{l}54.96 \pm 0.49 \\
540.49\end{array}$ & & & $0.93 \overline{-0.07}$ & $0=-$ & $0.14 \overline{ \pm} 0.05$ & $38.80 \pm 0.06$ & $0.32=$ & \pm 0.11 & $1.08 \pm 0.54$ & - & Pyrrhotite & & & \\
\hline $522 \mathrm{~B}-4$ & $54.59 \pm 0$ & $13.33 \pm 0.36$ & $\begin{array}{l}0.13 \pm 0.13 \\
0.17 \pm 0.16\end{array}$ & $\begin{array}{l}0.93 \pm 0.07 \\
0.86 \pm 0.17\end{array}$ & $\begin{array}{l}0.54 \pm 0.03 \\
0.52 \pm 0.02\end{array}$ & $\begin{array}{l}0.14 \pm 0.05 \\
0.14 \pm 0.06\end{array}$ & $\bar{z}$ & & $\bar{z}$ & $\bar{z}$ & $\bar{z}$ & $\begin{array}{l}\text { Titanomagnetite } \\
\text { Titanomagnetite }\end{array}$ & $\begin{array}{l}140 \\
150\end{array}$ & $\begin{array}{l}57 \\
65\end{array}$ & $\begin{array}{l}0.12 \\
0.19\end{array}$ \\
\hline \multirow[t]{2}{*}{$524-31-2,61-63$} & $52.55 \pm 0.58$ & $14.36 \pm 0.23$ & $0.57 \pm 0.29$ & $0.49 \pm 0.17$ & $0.72 \pm 0.22$ & $0.10 \pm 0.02$ & - & & - & - & - & Titanomagnetite & 335,520 & 245 & (a) \\
\hline & 35.80 & 29.49 & 1.17 & 0.09 & 0.62 & 0.04 & - & & - & - & - & Ilmenite & & & \\
\hline \multirow[t]{2}{*}{$524-31-2,61-63$} & $52.55 \pm 1.80$ & $14.36 \pm 1.11$ & $0.57 \pm 0.06$ & $0.49 \pm 0.10$ & $0.72 \pm 0.13$ & $0.10 \pm 0.08$ & - & & - & - & - & Titanomagnetite & 335 & 165 & 0.78 \\
\hline & $\begin{array}{l}35.35 \pm 0.03 \\
46.71 \pm 0.13\end{array}$ & $30.17 \pm 0.01$ & $1.11 \pm 0.16$ & $0.05 \pm 0.01$ & $0.63 \pm 0.02$ & $0.05 \pm 0.0$ & $49.17 \pm 0.71$ & $0.11=$ & \pm 0.02 & $\overline{-}$ & $0.01 \pm 0.01$ & $\begin{array}{l}\text { Ilmenite } \\
\text { Pyrite }\end{array}$ & & & \\
\hline \multirow[t]{2}{*}{$524-33-2,104-106$} & $\begin{array}{l}54.39 \pm 1.02 \\
36.09\end{array}$ & $\begin{array}{l}12.80 \pm 0.57 \\
30.05\end{array}$ & $\begin{array}{l}0.39 \pm 0.14 \\
0.28\end{array}$ & $\begin{array}{l}0.93 \pm 0.32 \\
0.05\end{array}$ & $\begin{array}{l}0.57 \pm 0.12 \\
0.57\end{array}$ & $\begin{array}{l}0.16 \pm 0.08 \\
0.14\end{array}$ & $=$ & & $=$ & $\bar{z}$ & 二 & $\begin{array}{l}\text { Titanomagnetite } \\
\text { Ilmenite }\end{array}$ & 300 & 145 & 0.72 \\
\hline & $46.80 \pm 0.18$ & 30.00 & 0.20 & 0.03 & - & $0^{0.14}$ & $51.45 \pm 0.82$ & 0.06 & \pm 0.00 & $=$ & 0.01 & Pyrite & & . & \\
\hline \multirow[t]{2}{*}{$524-34-1,36-38$} & $55.19 \pm 0.46$ & $12.50 \pm 0.65$ & $0.57 \pm 0.12$ & $1.01 \pm 0.29$ & $0.52 \pm 0.10$ & $0.12 \pm 0.08$ & - & & - & - & - & Titanomagnetite & 260 & 165 & 0.63 \\
\hline & $4 \pm 0.18$ & - & - & - & - & - & $39.36 \pm 0.13$ & $0.20=$ & \pm 0.10 & $0.39 \pm 0.01$ & - & Pyrrh & & & \\
\hline $524-34-1,90-92$ & $55.01 \pm 0.77$ & $13.19 \pm 0.50$ & $0.36 \pm 0.10$ & $0.89 \pm 0.18$ & $0.51 \pm 0.07$ & $0.12 \pm 0.08$ & - & & - & - & - & Titanomagnetite & 270 & 155 & 0.68 \\
\hline $524-34-2,13-15$ & $53.36 \pm 0.78$ & $12.95 \pm 0.44$ & $0.29 \pm 0.19$ & $1.24 \pm 0.21$ & $0.61 \pm 0.07$ & $0.29 \pm 0.17$ & - & & - & - & - & Titanomagnetite & 275,505 & 170 & (a) \\
\hline
\end{tabular}

Note: Cu was not found in any of the samples analyzed.

Titanomagnetite grains show signs of deuteric high temperature oxidation.

calculated from the present microprobe analyses with accuracy, because the cation ratio of the titanomagnetites changes with increasing low temperature oxidation (Prévot et al., 1968; Johnson and Melson, 1978; Petersen et al., 1979).

The pyrrhotite analyses give a composition close to $\mathrm{Fe}_{9} \mathrm{~S}_{10}$, a composition that according to Schwarz and Vaugham (1972) is only very weakly ferrimagnetic.

\section{ACKNOWLEDGMENTS}

The microprobe analyses were performed at the Institute of Geology of the University of Edinburgh. The help of Dr. P. Hill during these measurements is gratefully acknowledged. This study has been supported financially by the Deutsche Forschungsgemeinschaft.

\section{REFERENCES}

Grommé, C. S., Wright, T. L., and Peck, D. L., 1969. Magnetic properties and oxidation of iron-titanium oxide minerals in Alae and Makaopuhi lava lakes, Hawaii. J. Geophys. Res., 74: 5277-5293.
Johnson, H. P., and Hall, J. M., 1978. A detailed rock magnetic and opaque mineralogy study of the basalts from Nazca plate. Geophys. J. R. Astron. Soc., 52:45-64.

Johnson, H. P., and Melson, W. G., 1979. Electron microprobe analyses of some titanomagnetite grains from Hole 395A. In Melson, W. G., Rabinowitz, P. D., et al., Init. Repts. DSDP, 45: Washington (U.S. Govt. Printing Office), 575-579.

Lowrie, W., 1977. Intensity and direction of magnetization of oceanic basalts. J. Geol. Soc. London, 133:61-82.

O'Reilly, W., and Banerjee, S. K., 1966. Oxidation of titanomagnetites and self-reversal. Nature, 221:26-28.

Petersen, N., Eisenach, P., and Bleil, U., 1979. Low temperature alteration of the magnetic minerals in ocean floor basalts. Am. Geophys. Union, Maurice Ewing Ser., 2:169-209.

Prevot, M., Remond, G., and Caye, R., 1968. Etude de la transformation d'une titanomagnétite en titanomaghémite dans une roche volcanique. Bull. Soc. Fr. Mineral. Cristallogr., 91:65-74.

Schwarz, E. J., and Vaugham, P. J., 1972. Magnetic phase relations of pyrrhotite. J. Geomagn. Geoelectr., 24:441-458.

Date of Initial Receipt: August 25, 1983 